\title{
Control algorithms for PV and Heat Pump system using thermal and electrical storage
}

\author{
Emmanouil Psimopoulos ${ }^{1,2}$, Lorenz Leppin ${ }^{1}$, Rasmus Luthander ${ }^{2}$, Chris Bales $^{1}$ \\ ${ }^{1}$ Energy Technology, Dalarna University, Borlänge, Sweden \\ ${ }^{2}$ Department of Engineering Sciences, Uppsala University, Uppsala, Sweden
}

\begin{abstract}
In this study a detailed model of a single-family house with an exhaust air heat pump and photovoltaic system is developed in the simulation software TRNSYS. The model is used to evaluate three control algorithms using thermal and electrical storage in terms of final energy, solar fraction, self-consumption and seasonal performance factor. The algorithms are tested and compared with respect to energetic improvement for 1) use of the heat pump plus storage tank for domestic hot water and space heating, 2) use of the electrical storage in batteries and (3) use of both electrical and thermal storage. Results show the highest increase of self-consumption to $50.5 \%$, solar fraction to $40.6 \%$ and final energy decrease to $6923 \mathrm{kWh}$ by implementing the third algorithm in a system with $9.36 \mathrm{~kW}$ PV capacity and battery storage of $10.8 \mathrm{kWh}$. The use of electrical energy storage has higher positive impact compared to the thermal storage with the settings and component sizes used. The combined use of thermal storage and batteries leads to final energy savings that are nearly the same as the combined savings of thermal storage and batteries separately, showing that they are mostly independent of one another for the settings of this study.
\end{abstract}

Keywords: Photovoltaics, heap pump, thermal storage, electrical storage, solar fraction, self-consumption

\begin{tabular}{ll}
\multicolumn{2}{l}{ Nomenclature } \\
COP & Coefficient of performance \\
DHW & Domestic hot water \\
FE & Final energy \\
HP & Heat pump \\
SC & Self-consumption $[\%]$ \\
SF & Solar fraction $[\%]$ \\
SH & Space heating \\
SPF & Seasonal performance factor \\
PV & Photovoltaics
\end{tabular}

\section{Introduction}

The energy consumption in the building sector has increased steadily in developed countries for several years, reaching $20-40 \%$ of the total energy consumption with Sweden in the upper end of the scale in 2015 (Heier et al., 2015; Pérez-Lombard et al., 2008; Swedish Energy Agency, 2015a). Domestic hot water (DHW) and space heating (SH) accounted for more than half of the sector's total energy use (Swedish Energy Agency, 2015a). There are several options for supplying thermal energy for DHW and SH in the 
building stock, including district heating, electric heating, biofuels and fossil fuels. In Swedish single-family houses electric heating is the most common option with a share of $45 \%$ of the total heat demand in the sector in 2014 (Swedish Energy Agency, 2015b). For houses with electric heating, a heat pump (HP) combined with a hot water storage tank is an efficient way to lower the electricity demand for heating in an electrically heated house (Hirvonen et al., 2016; Swedish Energy Agency, 2015a).

\subsection{Energy management in buildings}

There are two ways to reduce the need of buying electricity in a household: either using solutions for energy savings or producing own electricity. This paper focuses on the latter method to lower the need of buying electricity from a retailer by using photovoltaics (PV) for in-house electricity production. PV for residential applications is becoming more popular in Sweden due to lower prices for turnkey systems and enhanced economic supporting schemes for micro-producers of electricity (Lindahl, 2016). The cumulative installed PV capacity in Sweden has increased remarkably during the past years, from a total of $11 \mathrm{MW}$ in 2010 to $127 \mathrm{MW}$ at the end of 2015, of which 30\% was residential grid-connected PV systems.

With an electric HP more of the PV electricity can be used in the house in comparison to non-electric heated houses. This can be an advantage both from an economical point of view and from a power system's perspective. If the buying prices of electricity exceed the selling prices, it is more profitable to replace bought electricity by own PV electricity than to sell the excess production to the power grid. A higher use of the PV electricity also lowers the excess electricity from the PV system, which might reduce the stress on the power grid in areas with a large penetration of PV.

Apart from converting electricity to heat via a heat pump, batteries for electricity storage or load shifting of electric appliances can be used to increase the use of PV electricity in the house (Castillo-Cagigal et al., 2011; Widén, 2014). The advantage of batteries is the possibility to store electricity for later use, while heat pumps can convert electricity into heat but not back again. Heat pumps can, however, have a higher thermal output than electric output, known as the coefficient of performance (Binder et al., 2012). This means that the efficiency of converting and storing electric energy as thermal energy can exceed $100 \%$ whereas the efficiency of battery storage always is below $100 \%$ due to conversion and storage losses. By time-shifting electric appliances such as washing and drying machines to times when there are high PV production, both self-consumption and solar fraction can be improved. The economic benefit for load shifting in the Swedish single-family building stock might, however, be low. A study of 200 houses in Sweden showed the economic benefit of load shifting to be maximum 20 Euro per house and year (Widén, 2014).

\subsection{Final energy, solar fraction, self-consumption and seasonal performance factor}

Apart from the electricity production, there are three measures that are useful to evaluate the energy performance of a residential PV system, namely, final energy consumption, self-consumption and solar fraction. Furthermore, a heat pump can be evaluated based on its seasonal performance factor.

Final energy (FE) consumption refers to the energy supplied to a customer (European Environment Agency, 2016). In this study the final energy is the electricity that needs to be bought from an electricity retailer over the studied year. Self-consumption is defined as PV electricity production that is directly consumed in the house, i.e. self-consumed electricity, relative to the total PV electricity production (Baetens et al., 2012). Solar fraction is defined as the self-consumed PV electricity production relative to the total load (Lund, 2005).

A mathematical description of self-consumption and solar fraction can be found in Luthander et al. (2015). If $L(t)$ denotes the instantaneous electric load including appliances, heat pump and auxiliary heater, and $P(t)$ is the instantaneous power from the PV system, the directly consumed PV power $M(t)$ can be defined as

$$
M(t)=\min \{L(t), P(t)\}
$$

if no electric storage is used. When adding battery storage to the system, this can be extended to

$$
M(t)=\min \{L(t), P(t)+S(t)\}
$$

where $S(t)<0$ denotes power to storage (charging) and $S(t)>0$ denotes power from storage (discharging). The final energy for the simulation period is equal to the electric load that cannot be supplied by PV 
electricity:

$$
F E=\int_{t_{1}}^{t_{2}} L(t) d t-\int_{t_{1}}^{t_{2}} M(t) d t
$$

Self-consumption and solar fraction can then be defined as:

$$
\begin{array}{r}
S C=\frac{\int_{t_{1}}^{t_{2}} M(t) d t}{\int_{t_{1}}^{t_{2}} P(t) d t} \\
S F=\frac{\int_{t_{1}}^{t_{2}} M(t) d t}{\int_{t_{1}}^{t_{2}} L(t) d t}
\end{array}
$$

Strategies for improving PV self-consumption and solar fraction in residential buildings are a rapidly expanding research field (Luthander et al., 2015). The majority of the studies focus on PV in combination with battery storage but heat pumps plus hot water storage have also attracted some interest in recent years (Binder et al., 2012; Hesaraki and Holmberg, 2013; Hirvonen et al., 2016; Luthander et al., 2015; Thygesen and Karlsson, 2014).

Seasonal performance factor (SPF) is a measure of the efficiency of the heat pump, defined as the heat output relative to the electric input. In this study two definitions are used, the first $S P F_{H P}$ includes only the HP compressor electric input and the second $S P F_{H P+a u x}$ includes both the HP compressor electric input and the auxiliary input. Since the use of a heat pump system in cold regions is higher in the winter months when the solar irradiance and thus PV electricity production is low, the SPF of the heat pump may have a large impact on the yearly final energy. SPF can be defined as:

$$
\begin{gathered}
S P F_{H P}=\frac{\int_{t_{1}}^{t_{2}}\left[Q_{S H}(t)+Q_{D H W}(t)\right] d t}{\int_{t_{1}}^{t_{2}} P_{e l, H P}(t) d t} \\
S P F_{H P+a u x}=\frac{\int_{t_{1}}^{t_{2}}\left[Q_{S H}(t)+Q_{D H W}(t)\right] d t}{\int_{t_{1}}^{t_{2}}\left[P_{e l, H P}(t)+P_{e l, a u x}(t)\right] d t}
\end{gathered}
$$

Where $Q_{S H}(t)$ is the instantaneous heating power for the SH and the $Q_{D H W}(t)$ is the instantaneous heating power for the DHW respectively. $P_{e l, H P}$ denotes the instantaneous power of the HP's compressor and $P_{e l, a u x}$ the instantaneous power of the auxiliary input.

\subsection{Aim and novelty}

In this paper, control algorithms for residential PV, heat pump and battery storage systems are evaluated for a single family house in Sweden in terms of self-consumption, solar fraction and final energy. A detailed model of a new single-family house with a typical grid connected PV system, exhaust air heat pump and hot water storage tank is defined and modelled on the simulation software TRNSYS 17. The model is further developed by regulating the heat pump based on PV power production and by using battery energy storage.

The aim of the study is to maximize the self-consumption and solar fraction and to minimize the final energy by using control algorithms for the heat pump and battery storage. The novelty of this study is the combined use of a detailed and validated house model, measured high-resolution weather data and detailed load profiles for both DHW and electric load. The stochastical load patterns are based on monitoring data for single family houses (Widén et al., 2012, 2009). All these are implemented in the simulation software TRNSYS where the components are designed to meet the specifications of existing products of a house, heat pump, hot water tank and battery storage available on the market today.

\section{Models and boundary conditions}

This section describes the models of the house and PV system, heat pump and hot water storage tank, battery storage as well as the boundary conditions of the whole system.

\subsection{House model and boundary conditions}

The modelled house is a typical Swedish single floor, single family house (SFH) with a gabled roof, an overall U-value of $0.2 \mathrm{~W} \mathrm{~m}^{-2} \mathrm{~K}^{-1}$ and $143 \mathrm{~m}^{2}$ heated floor area, see Tab. 1. A detailed model of the house 
with six zones using space heating, developed in the simulation software TRNSYS, is described in detail and validated by Persson and Heier (2010). TRNSYS' type 56 is used for the house model. A schematic figure of the house with its zones is found in Fig. 1. The set temperatures in the zones (rooms) differ from $20^{\circ} \mathrm{C}$ in zone 3,5 and $6,21^{\circ} \mathrm{C}$ in zone 1 and 2 , and $22^{\circ} \mathrm{C}$ in zone 4 (Persson and Heier, 2010). The SH is switched on when the temperature falls $1^{\circ} \mathrm{C}$ below the set temperatures in either of the zones.

Tab. 1: Geometrical and thermal properties of the studied house (Persson and Heier, 2010)

\begin{tabular}{ccc}
\hline & Total area $\left[\mathbf{m}^{2}\right]$ & U-value $\left[\mathbf{W} \mathbf{~ m}^{-2} \mathbf{K}^{-1}\right]$ \\
\hline Outer walls & 107 & 0.23 \\
Roof & 153 & 0.09 \\
Floor & 143 & 0.10 \\
Windows & 24 & 1.27 \\
Doors & 5 & 0.54 \\
Mean U-value & & 0.20
\end{tabular}

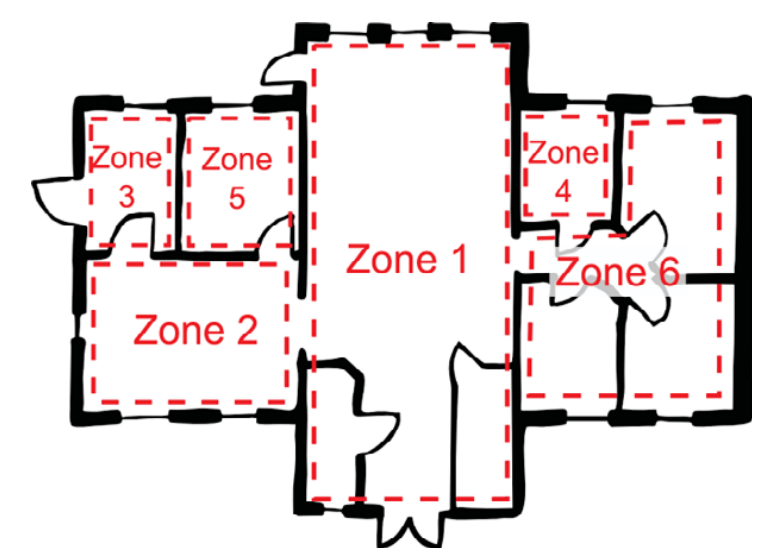

Fig. 1: Schematic figure of the house and the temperature zones (Persson and Heier, 2010)

The location of the house is Norrköping, Sweden $\left(58.6^{\circ} \mathrm{N}, 16^{\circ} 2 \mathrm{E}\right)$. Measured high-resolution (one minute) meteorological data by the Swedish Meteorological and Hydrological Institute (SMHI) from the year 2007 in Norrköping is used in the simulations. The weather data is used both for calculation of the PV electricity production and for calculations of energy gains and losses in the house.

Fresh water temperature, which affects the heating demand, is dependent on the time of the year and modelled on a function described by Heimrath and Haller (2007). Two adults and two children are living in the house, and the internal heat energy gain, assumed to be the same as the electricity consumption for appliances, are calculated using a Markov-chain model for occupancy and energy use described in Widén et al. (2009). The DHW demand is derived from the MacSheep project and adjusted for this study, see Table 2 (Bales et al., 2015). All variables are in a 2 minute resolution over the period of one year.

Tab. 2: DHW and appliance data (Bales et al., 2015)

\begin{tabular}{cc}
\hline 2979 & Discharge energy $\left[\mathrm{kWh}_{\text {year }}{ }^{-1}\right]$ \\
70.9 & Discharge volume $\left[\mathrm{m}^{3}\right.$ year $\left.^{-1}\right]$ \\
45 & Discharge temperature $\left[{ }^{\circ} \mathrm{C}\right]$ \\
194.2 & Daily Average draw-off $[\mathrm{kg}]$ \\
$2.44-972.2$ & Flow $\left[\mathrm{kg} \mathrm{h}^{-1}\right]$ \\
3437 & Electricity for appliances $\left[\mathrm{kWh}\right.$ year $\left.{ }^{-1}\right]$ \\
5650 & Max load for appliances $[\mathrm{W}]$ \\
\hline
\end{tabular}




\subsection{Hot water storage tank, heat pump and auxiliary heater}

A variable speed, exhaust air HP delivers heat both for SH and DHW but cannot supply them both at the same time. The HP model is based on the performance map of the HP, with heat capacity and power input as dependent variables together with inlet air temperature, inlet air flow rate and compressor speed as independent variables. SH is turned on in each zone when the room temperature falls below a lower limit, see Section 2.1. This means that the SH can be on for one zone but not for the rest. A hot water storage tank of 180 litres is used for DHW whereas the SH is supplied by the HP through a buffer store of 25 litres. The HP is activated according to a heating curve and compensatory control algorithm dependent on the SH supply temperature. An electric auxiliary heater is activated when the thermal power provided by the heat pump is insufficient to meet thermal power need. The auxiliary heater is inactivated during the predefined summer period. Preferences that are used for this study of the DHW storage, heat pump and auxiliary heater can be found in Table 3. The models for HP including storage and control algorithms are based on one of the most common commercial products on the market.

Tab. 3: Specifications of hot water storage tank, exhaust air heat pump and auxiliary heater

\begin{tabular}{cc}
\hline Preference & Quantity/name \\
\hline DHW storage tank capacity $[\mathrm{litre}]$ & 180 \\
Electric compressor power $[\mathrm{kW}]$ & $0.27-2.05$ \\
Thermal power of HP $[\mathrm{kW}]$ & $1.14-4.99$ \\
Heat pump COP & $2.4-4.7$ \\
Electric auxiliary heater $[\mathrm{kW}]$ & $0.5-6.5$ \\
\hline
\end{tabular}

\subsection{Battery storage and PV system}

Three PV system sizes and three battery storage sizes are used to study the impact on the performance in terms of self-consumption, solar fraction and final energy, see Tab. 4. The tilt angle is defined by the roof of the building whereas the azimuth angle is chosen to optimize the yearly PV electricity production. The PV panels, inverter and batteries are modelled on products available on the market.

Tab. 4: Specifications of the PV system and battery storage

\begin{tabular}{cc}
\hline Preference & Quantity/name \\
\hline Capacity PV $[\mathrm{kW}]$ & $3.12,5.7,9.36$ \\
Inverter efficiency [\%] & 97.7 \\
PV tilt $\left[^{\circ}\right]$ & 27 \\
PV azimuth $\left[^{\circ}\right]$ & 0 \\
Capacity battery [kWh] & $3.6,7.2,10.8$ \\
Battery technology & Lithium-ion \\
Battery losses [\%] & $10 \%$ \\
\hline
\end{tabular}

\section{Control algorithms for increased self-consumption}

A base case and three control algorithms for improving the energy performance of the system are developed and evaluated:

- The base case includes the house equipped with a PV system and a heat pump for DHW storage and $\mathrm{SH}$. The HP is controlled solely by the need of SH and the temperature in the DHW storage tank.

- First control algorithm is applied to the base case system. The heat pump is controlled by excess PV production to increase self-consumption. 
- Second control algorithm is applied to the base case system with added battery storage. Charging and discharging of the batteries are controlled by excess PV production to increase self-consumption whereas the HP is controlled solely by the need of SH and temperature in the DHW storage tank.

- Third control algorithm is for the base case system with usage of both thermal storage and batteries. Excess PV power production is first used to charge the batteries, thereafter the HP is switched on if possible.

A flow chart showing the control scheme for on-off control of the HP for the case of algorithm 3, can be found in Figure 2. Moreover, since the algorithm 3 is the combination of algorithm 1 and 2 the flow chart contains all the three algorithms.

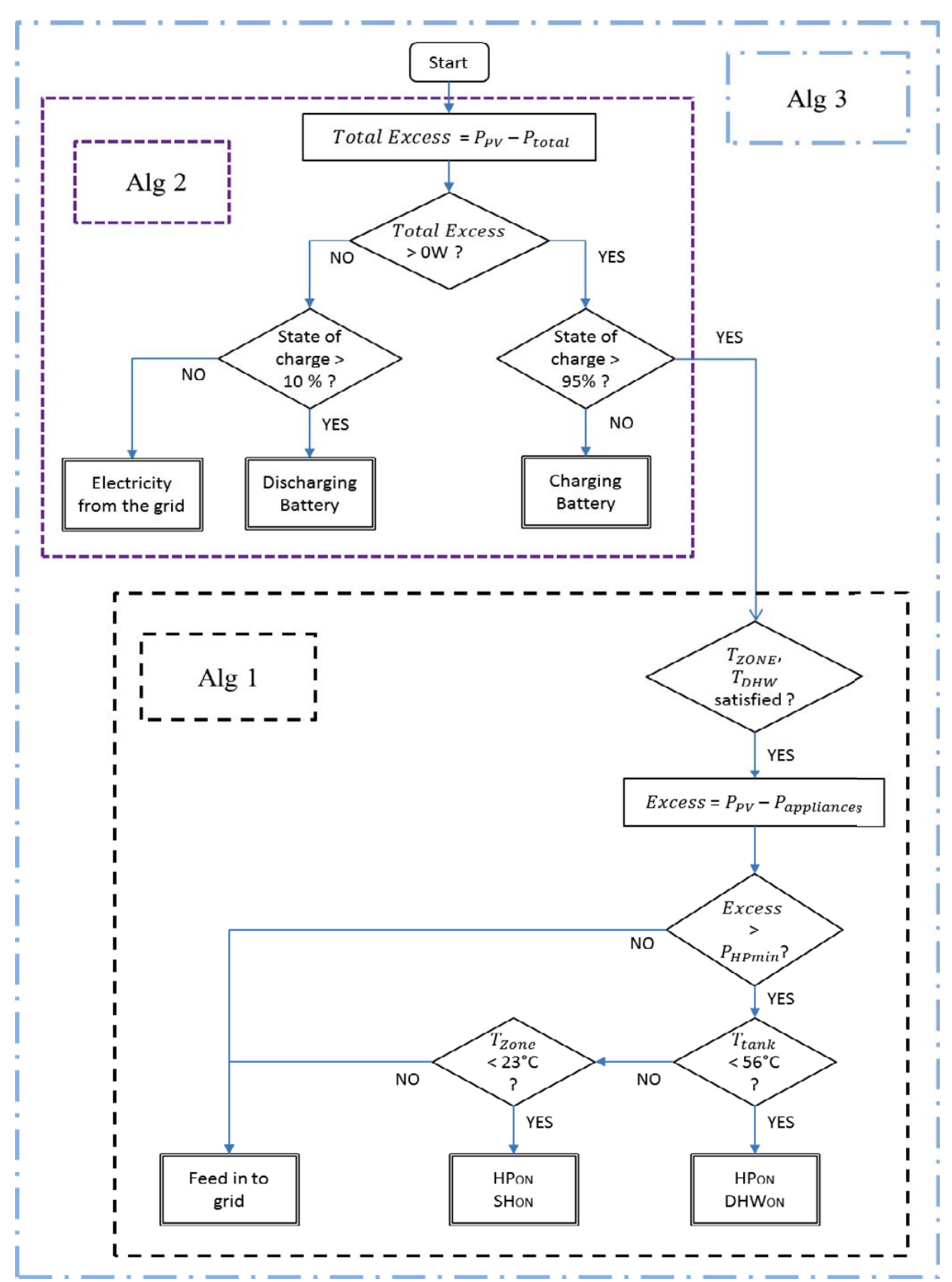

Fig. 2: Flow chart for control scheme to utilize excess PV power combining electrical with thermal storage (algorithm 1-3). 
In algorithms 1 and 3, excess PV power production can switch on the HP even if no SH is needed and the DHW storage temperature is above the lower temperature limit. This is used to increase the self-consumption of PV electricity production and lower the demand of buying electricity at later times. The temperature in the DHW storage must be below than the upper temperature limit as well as the maximum allowed individual zone temperature, to allow the HP to be operated based on PV excess production. In order for the HP to be activated and increase the thermal storage either by DHW or by SH a minimum power limit of the excess PV electricity is required which is the $P_{H P m i n}$.

\section{Results}

A comparison of the key figures such as self-consumption, solar fraction and final energy is given in Table 6 for base case, while Table 5 gives the heat and electricity use of the building and its occupants. For the base case system the self-consumption varies from 43 to $23 \%$ while solar fraction varies from 12 to $19 \%$ with increasing PV size. The SPF of the HP is 2.67 while that for the system (HP plus auxiliary electrical heater) is only 2.35 due to the relatively large amount of auxiliary energy used.

Tab. 5: Heat and electricity use of the base case

\begin{tabular}{|c|c|c|c|}
\hline Electrical energy & & kWh year-1 & \\
\hline Electrical appliances & & 3437 & \\
\hline Heat pump & & 6506 & \\
\hline Auxiliary heater & & 1380 & \\
\hline Thermal energy & & kWh year-1 & \\
\hline SH load & & 14923 & \\
\hline DHW load & & 2979 & \\
\hline DHW tank losses & & 669 & \\
\hline \multicolumn{4}{|c|}{ Tab. 6: Key results for the base case system } \\
\hline PV capacity & $3.1 \mathrm{~kW}$ & $5.7 \mathrm{~kW}$ & $9.3 \mathrm{~kW}$ \\
\hline Electrical energy & & kWh year-1 & \\
\hline $\mathrm{PV}$ production $\mathrm{AC}$ & 3123 & 5914 & 9370 \\
\hline Measure & & Quantity & \\
\hline PV SC (annual) & $43 \%$ & $30.6 \%$ & $23.3 \%$ \\
\hline PV SF (annual) & $11.9 \%$ & $16 \%$ & $19.3 \%$ \\
\hline Final energy & 9981 & 9499 & 9116 \\
\hline
\end{tabular}

The system was simulated for each of the algorithms with the three different PV sizes, each with its own storage size chosen according to the PV capacity $(3.1 \mathrm{~kW} / 3.6 \mathrm{~kW}, 5.7 \mathrm{~kW} / 7.2 \mathrm{kWh}, 9.3 \mathrm{~kW} / 10.8 \mathrm{kWh})$. The results can be seen in Figure 3, where FE, SC and SF are shown for the base case and the three algorithms for all three PV sizes. Algorithm 2 (batteries) gives far greater savings (reduction in FE compared to base case) than algorithm 1 (thermal storage), and this difference is greater for larger PV sizes. For the largest PV size, algorithm 2 saves three times as much FE as algorithm 1 does. The savings for algorithm 3 are only slightly less than the sum of the savings of the algorithms 1 and 2 separately. This shows that the two algorithms are compatible and additive and hardly competing for the PV electricity. The savings in final energy for algorithm 3 (compared to base case) are 837, 1573 and $2193 \mathrm{kWh}$ for the 3.1, 5.7 and $9.3 \mathrm{~kW}$ PV sizes respectively. 


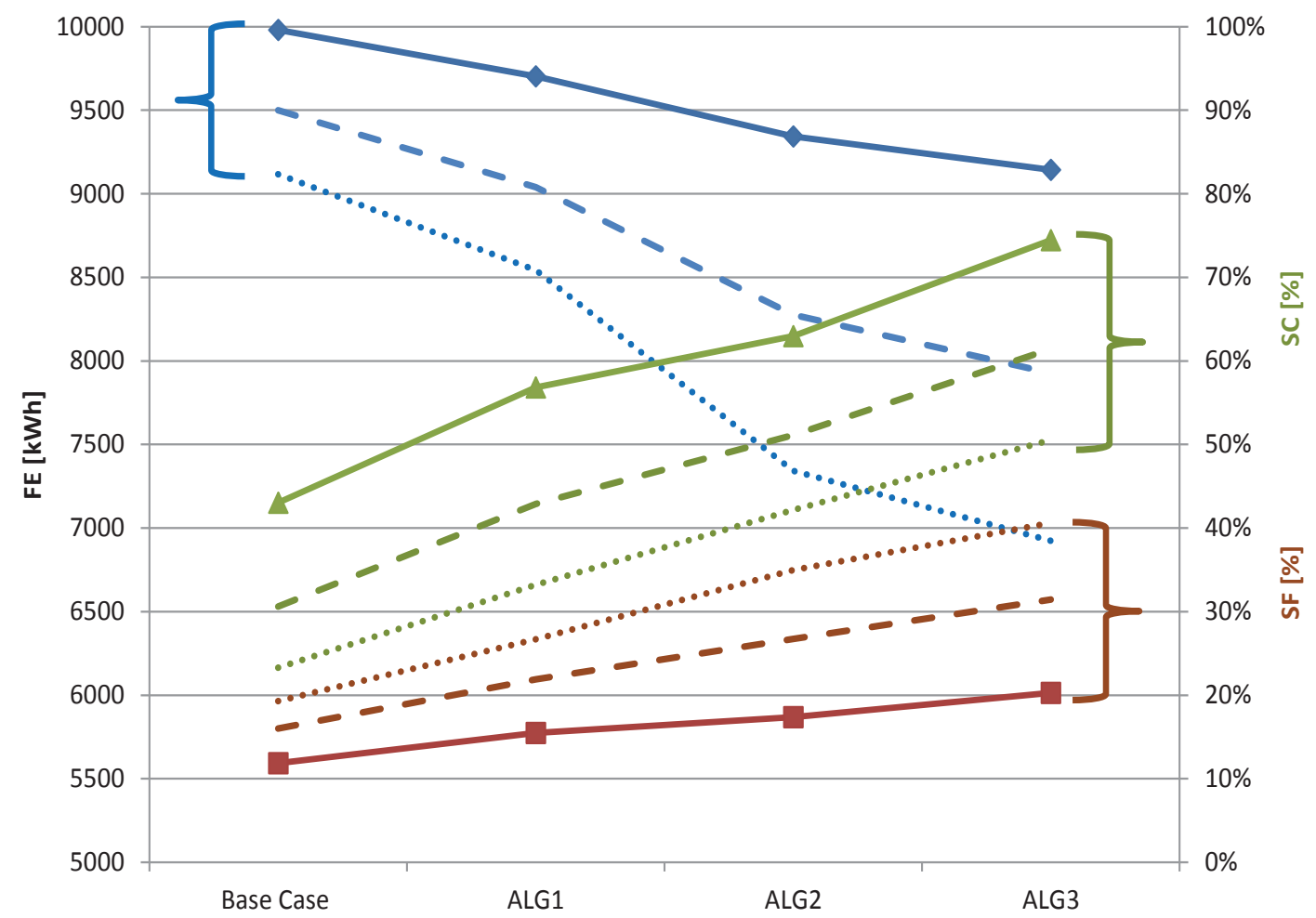

Fig 3: Comparison of the key figures between the base case and the control algorithms 1, 2 and 3. Final energy in blue (diamonds), self-consumption in green (triangles) and solar fraction in brown (squares). The PV sizes are denoted with solid lines $(3.1 \mathrm{~kW})$, dashed lines $(5.7 \mathrm{~kW})$ and dotted lines $(9.3 \mathrm{~kW})$.

The annual electricity production is $3120 \mathrm{kWh}$ for a system of $3.1 \mathrm{~kW}$. Key figures for the base case and the same PV system size using the third algorithm are presented in Table 7. $\mathrm{SPF}_{\mathrm{HP}}$ is lower for algorithm 3 than for the base case, while the values for $\mathrm{SPF}_{\mathrm{HP}+\mathrm{aux}}$ are the same. This is because the algorithm using thermal storage leads to increased operating temperatures in the HP, reducing the COP. However, the auxiliary does not have to supply as much energy, which in this case happens to cancel out the negative effect of lower COP.

Tab. 7: Key figures for the base case system of $3.1 \mathrm{~kW} \mathrm{PV}$ and the control algorithm 3 with $3.1 \mathrm{~kW}$ PV.

\begin{tabular}{ccc}
\hline & Base case & Alg3 \\
\hline Electrical energy & \multicolumn{2}{c}{ kWh year-1 } \\
PV production AC & \multicolumn{2}{c}{3123} \\
Heat pump & 6506 & 6805 \\
Auxiliary heater & 1380 & 1223 \\
\hline Measure & \multicolumn{3}{c}{ Quantity } \\
\hline PV SC (annual) & $43 \%$ & $74.5 \%$ \\
PV SF (annual) & $11.9 \%$ & $20.3 \%$ \\
Final energy & 9981 & 9144 \\
SPF $_{\mathrm{HP}}$ & 2.67 & 2.59 \\
$\mathrm{SPF}_{\mathrm{HP}+\text { aux }}$ & 2.35 & 2.35 \\
\hline
\end{tabular}


a

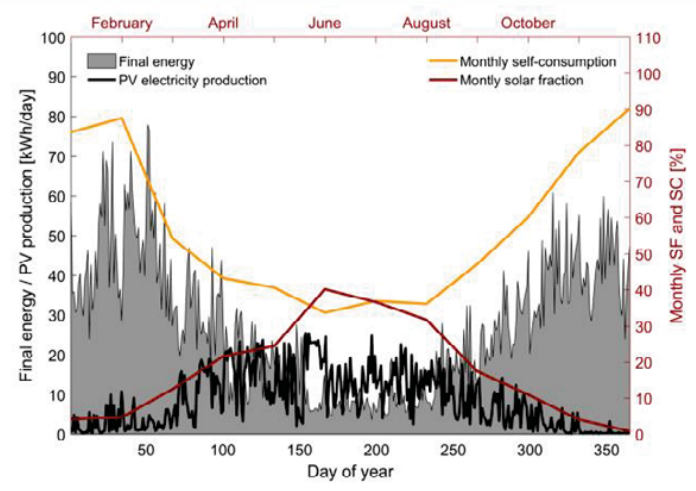

b

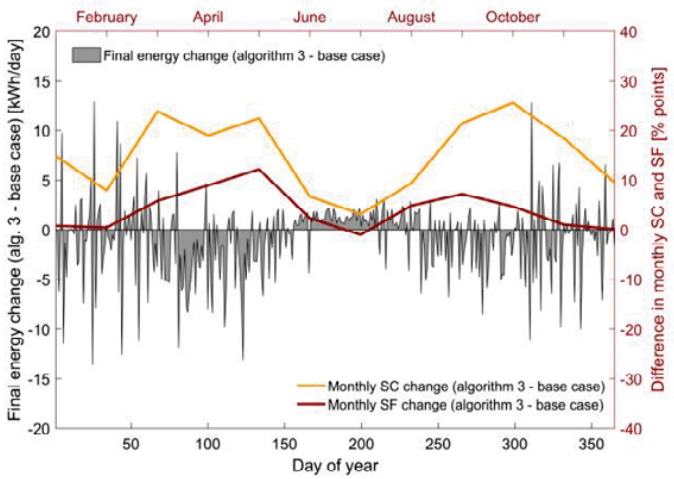

Fig 4: Daily final energy and production and monthly solar fraction and self-consumption for the base case (a) and the result with the third algorithm applied (b).

The monthly solar fraction varies much over the year, reaching $40 \%$ in June but is below $10 \%$ in November to February as seen in Figure 4a. With the third algorithm the solar fraction, as well as self-consumption, can be improved, most notably in the spring, see Figure $4 \mathrm{~b}$. Solar fraction, self-consumption and final energy are calculated with minute values of production and consumption. If aggregated monthly values would be used instead for the calculations, the solar fraction would get near to $100 \%$ in the summer.

\section{Discussion}

In order to increase the self-consumption, the temperature in the DHW tank is sometimes exceeding the set temperature during periods with high excess PV power production. Although the total electricity consumption by the HP is increasing due to higher heat losses, the final energy will be reduced due to a lower need of HP operation during periods without excess PV production.

Figure $4 \mathrm{~b}$ shows that there are times during the year when the final energy is greater with algorithm 3 than for the base case, but for the whole year there are significant savings ( $837 \mathrm{kWh}$ for $3.1 \mathrm{~kW}$ PV system). This shows that there is still some potential for improving the algorithms.

The climate conditions in Sweden with negative seasonal correlation between irradiance and outdoor temperature make it difficult for a regular single-family house to be completely independent of the power grid. For an off-grid system either large storage units or a drastically changed behavior are needed. Therefore, a reliable power grid that can handle both high power demand as well as high power production is needed for a larger integration of PV in the Swedish power system.

The performance map of the HP is defined for constant water flow rate, but in practice the system flow for SH and DHW is variable, which will affect both the capacity and COP of the HP. This effect has not been taken into account in the study.

To minimize the final energy the solar fraction should be high and to minimize excess PV electricity production the self-consumption should be high. The highest PV power production occurs in the summer which coincides with low electricity demand, see Figure 4 . The need of thermal energy for space heating is low in the summer but there is still a need of DHW. For the Swedish climate and indoor temperature of 22 ${ }^{\circ} \mathrm{C}$ in the bathroom, there is only a short period when no heating is required. The heat pump and thermal storage can therefore be operated to minimize both final energy and excess PV electricity 


\section{Conclusion}

This study shows the potential of increasing the self-consumption of a residential PV system and reducing the final energy. The base case with a PV system of $3.1 \mathrm{~kW}$ and a heat pump operating independently of PV excess power production has a self-consumption of $43 \%$, final energy of $9981 \mathrm{kWh}$ and solar fraction of $12 \%$ for the simulated year.

- $\quad$ The use of the existing thermal storage gives a decrease in final energy of 279 to $573 \mathrm{kWh}$ per year for the PV sizes of 3.1 to $9.3 \mathrm{~kW}$.

- The use of battery gives far greater decreases in FE than the use of the thermal storage, with the used settings and sizes of components.

- The combined use of thermal storage and batteries leads to final energy savings that are nearly the same as the combined savings of thermal storage and batteries separately, showing that they are mostly independent of one another for the settings of this study.

\section{References}

Baetens, R., De Coninck, R., Van Roy, J., Verbruggen, B., Driesen, J., Helsen, L., Saelens, D., 2012. Assessing electrical bottlenecks at feeder level for residential net zero-energy buildings by integrated system simulation. Appl. Energy 96, 74-83. doi:10.1016/j.apenergy.2011.12.098

Bales, C., Betak, J., Broum, M., Chèze, D., Cuvillier, G., Haberl, R., Hafner, B., Haller, M., Hamp, Q., Heinz, A., Hengel, F., Kruck, A., Matuska, T., Mojic, I., Petrak, J., Poppi, S., Sedlar, J., Sourek, B., Thissen, B., Weidinger, A., 2015. Optimized solar and heat pump systems, components and dimensioning: MacSheep - New Materials and Control for a next generation of compact combined Solar and heat pump systems with boosted energetic and exergetic performance [WWW Document]. URL http://www.macsheep.spf.ch/ (accessed 9.20.16).

Binder, J., Williams, C.O., Kelm, T., 2012. Increasing PV Self-Consumption, Domestic Energy Autonomy and Grid Compatibility of PV Systems Using Heat-Pumps, Thermal Storage and Battery Storage. 27th Eur. Photovolt. Sol. Energy Conf. Exhib. 4030-4034. doi:10.4229/27THEUPVSEC2012-5AV.1.55

Castillo-Cagigal, M., Caamaño-Martín, E., Matallanas, E., Masa-Bote, D., Gutiérrez, A., Monasterio-Huelin, F., Jiménez-Leube, J., 2011. PV self-consumption optimization with storage and Active DSM for the residential sector. Sol. Energy 85, 2338-2348. doi:10.1016/j.solener.2011.06.028

European Environment Agency, 2016. Final energy consumption by sector and fuel [WWW Document]. URL http://www.eea.europa.eu/data-and-maps/indicators/final-energy-consumption-by-sector-9 (accessed 7.14.16).

Heier, J., Bales, C., Martin, V., 2015. Combining thermal energy storage with buildings - a review. Renew. Sustain. Energy Rev. 42, 1305-1325. doi:10.1016/j.rser.2014.11.031

Heimrath, R., Haller, M., 2007. The Reference Heating System, the Template Solar System of Task 32 [WWW Document]. URL http://archive.iea-shc.org/publications/downloads/task32Reference_Heating_System.pdf (accessed 3.30.16).

Hesaraki, A., Holmberg, S., 2013. An investigation of energy efficient and sustainable heating systems for buildings: Combining photovoltaics with heat pump, in: Smart Innovation, Systems and Technologies. pp. 189-197. doi:10.1007/978-3-642-36645-1_18

Hirvonen, J., Kayo, G., Hasan, A., Sirén, K., 2016. Zero energy level and economic potential of small-scale building-integrated PV with different heating systems in Nordic conditions. Appl. Energy 167, 255269. doi:10.1016/j.apenergy.2015.12.037

Lindahl, J., 2016. National Survey Report of PV Power Applications in Sweden 2015 - IEA PVPS.

Lund, P.D., 2005. Sizing and applicability considerations of solar combisystems. Sol. Energy 78, 59-71. doi:10.1016/j.solener.2004.07.008

Luthander, R., Widén, J., Nilsson, D., Palm, J., 2015. Photovoltaic self-consumption in buildings: A review. Appl. Energy 142, 80-94. doi:10.1016/j.apenergy.2014.12.028

Pérez-Lombard, L., Ortiz, J., Pout, C., 2008. A review on buildings energy consumption information. Energy Build. 40, 394-398. doi:10.1016/j.enbuild.2007.03.007

Persson, T., Heier, J., 2010. Småhusens framtida utformning : Hur påverkar Boverkets nya byggregler? [How 
do the new Swedish building codes affect detached houses of the future?]. Region Gävleborg, Gävle, Sweden.

Swedish Energy Agency, 2015a. Energy in Sweden 2015.

Swedish Energy Agency, 2015b. Energistatistik för småhus 2014 [Energy statistics for detached houses 2014].

Thygesen, R., Karlsson, B., 2014. Simulation and analysis of a solar assisted heat pump system with two different storage types for high levels of PV electricity self-consumption. Sol. Energy 103, 19-27. doi:10.1016/j.solener.2014.02.013

Widén, J., 2014. Improved photovoltaic self-consumption with appliance scheduling in 200 single-family buildings. Appl. Energy 126, 199-212. doi:10.1016/j.apenergy.2014.04.008

Widén, J., Lundh, M., Vassileva, I., Dahlquist, E., Ellegård, K., Wäckelgård, E., 2009. Constructing load profiles for household electricity and hot water from time-use data - Modelling approach and validation. Energy Build.

Widén, J., Molin, A., Ellegård, K., 2012. Models of domestic occupancy, activities and energy use based on time-use data : deterministic and stochastic approaches with application to various building-related simulations. J. Build. Perform. Simulation, Taylor Fr. 5, 27-44. 